\title{
Erratum to: A Circumarctic Review of Contaminants in Ringed Seals
}

Katrin Vorkamp and Derek C.G. Muir

\section{Erratum to:}

Chapter 12 in: R. Kallenborn (ed.), Implications

and Consequences of Anthropogenic Pollution in Polar

Environments, From Pole to Pole,

DOI 10.1007/978-3-642-12315-3_12

The book was inadvertently published without incorporating the corrections in Chap. 12. The erratum book and the chapter has been updated.

The updated original online version for this chapter can be found at DOI 10.1007/978-3-642-12315-3_12

\footnotetext{
K. Vorkamp $(\bowtie)$

Department of Environmental Science, Aarhus University, Frederiksborgvej 399, 4000 Roskilde, Denmark

e-mail:kvo@envs.au.dku

D.C.G. Muir

Aquatic Contaminants Research Division, Environment Canada, Burlington,

ON L7R 4A6, Canada

(C) Springer-Verlag Berlin Heidelberg 2016 